This PDF is a selection from an out-of-print volume from the National Bureau of Economic Research

Volume Title: Long-Range Economic Projection

Volume Author/Editor: Conference on Research in Income and Wealth

Volume Publisher: NBER

Volume ISBN: 0-691-04141-5

Volume URL: http://www.nber.org/books/unkn54-1

Publication Date: 1954

Chapter Title: Projections in Agriculture

Chapter Author: James P. Cavin

Chapter URL: http://www.nber.org/chapters/c2932

Chapter pages in book: (p. $105-130)$ 
PART II 


\section{,}




\title{
PROJECTIONS IN AGRICULTURE
}

\author{
JAMES P. CAVIN \\ OFFICE OF STATISTICAL STANDARDS, BUREAU OF THE BUDGET
}

\section{A. INTRODUCTION}

THus paper reviews a number of economic projections which have been made by the Bureau of Agricultural Economics of the United States Department of Agriculture during the postwar period. I shall describe briefly the nature and purpose of these projections, summarize the methods used, and discuss a few of the problems involved.

Agriculture is only a segment of the national economy, but an important one. Net income from agriculture usually represents about 10 percent of total national income; about 18 percent of the population of the United States lives on farms; agricultural exports usually account for 25 to 30 percent of total exports; and American consumers spend over 35 percent of their total disposable income on such agricultural products as food, clothing, and tobacco.

The field of agricultural economics has traditionally been separated from the main body of economic analysis. The artificial character of this separation shows up sharply when long-term projections of the national product are under consideration. On the one hand, the agricultural economist becomes involved in many of the problems of population, labor force, productivity, the cost-wage-price structure, money supply, and the consumption function that confront the more general analyst. On the other hand, the general analyst must employ reasonable assumptions about the agricultural labor force, agricultural production, farm income, the prices of farm commodities, and the consumption of food, or some of his more general projections may become distorted.

This is not to imply that there is no room for specialization. The agricultural analyst, for example, needs a more detailed set

Note: The assignment to prepare this paper was undertaken while the author was head of the Division of Statistical and Historical Research, Bureau of Agricultural Economics, Department of Agriculture, and completed while he was, as he is now, a member of the staff of the Office of Statistical Standards, Bureau of the Budget. It does not necessarily represent the views of either agency. 
of projections for the agricultural segment than for the nonagricultural segment; while the reverse is true for the analyst specializing in problems of commerce, industry, or labor. Nevertheless, projective analyses, even with specialized objectives, must reckon with many factors whose influences permeate the entire economy.

\section{B. LONG-RUN PROJECTIONS}

The Bureau of Agricultural Economics has published two sets of relatively long-run projections for agriculture. The first appeared in a series of bulletins published in 1945 entitled What Peace Can Mean to American Farmers. The actual analysis was done largely in 1944, and the projections were for the year 1950. The second, published in 1948, was A Study of Selected Trends and Factors Relating to the Long-Run Prospect for American Agriculture, prepared for the Committee on Agriculture of the House of Representatives. The analysis was done in 1947 and the projections were for a postwar period described as being about 195565 , with some selected trends projected to 1975. This study is usually called the "Hope Report." This was not due to any wishful character, but to the fact that the request for its preparation came from the Hon. Clifford Hope, chairman of the House Agriculture Committee. We are now working on projective analyses in connection with river valley developments, flood control, soil conservation, and the activities of various agricultural lending agencies, all of which require consideration of whether future economic returns will justify current investment costs.

Before analyzing our longer-term projections, I shall dwell briefly on our outlook work. Each fall we make systematic appraisals of the economic prospects for agriculture during the coming calendar year. This work has been described elsewhere in some detail. ${ }^{1}$ Our work on longer-term projections grew out of these efforts at short-term forecasting, and to some extent a common methodology is employed.

\section{SHORT-TERM APPRAISALS}

In making our short-term appraisals, we first estimate the levels of domestic and foreign demand for farm products during the

1 J. P. Cavin, "Forecasting the Demand for Agricultural Products," Agricultural Economics Research (Bureau of Agricultural Economics), Vol. Iv, No. 3, July 1952, pp. 65-76. 


\section{AGRICULTURE}

coming year. This requires an estimate of disposable income and of the value of agricultural exports. From a number of sources we develop forecasts of gross private investment, net foreign investment, and government purchases of goods and services. These forecasts provide an estimate of nonconsumption expenditures from which we can estimate gross national product, personal income, and disposable income.

From the GNP forecast, plus information about foreign aid programs, we can estimate the anticipated value of agricultural exports. Cash receipts from livestock, livestock products, and crops marketed domestically can be estimated as a function of disposable income; while cash receipts from export crops can be estimated as a function of disposable income and the value of agricultural exports.

From our knowledge of the quantity of livestock, feed supplies, and crop conditions, we can estimate the probable level of farm output and farm marketings. Given the latter, together with the estimate of cash receipts, we can derive an estimate of the level of prices received by farmers. Furthermore, because of the close relationship between cash receipts and the realized net income of farm operators, an estimate of the former will usually yield a pretty fair estimate of the latter. I shall not try to give any of the details involved in these estimates, except to say that linear relationships, fitted by least squares, are employed throughout.

In making our general forecasts of farm prices and income, we do not rely exclusively on these over-all relationships. Our analysts specializing in the various commodity fields, who are responsible for outlook reports appraising the factors affecting the prices of their respective commodities, provide us with independent estimates of the prices and quantities involved, which we can use to substantiate or modify the forecasts for the larger aggregates.

Neither our short-term forecasts nor our longer-term projections hinge on any single method. We try to use and consolidate all relevant knowledge. We examine long-time trends in production, consumption, and technology; we employ various types of statistical relationships; and we utilize the specialized knowledge of commodity analysts, farm management experts, marketing specialists, and the like. We continually try new hypotheses and new statistical techniques, and attempt to bring within our grasp 
problems which we had to leave unsolved in earlier projective efforts.

The ways in which our longer-range projections differ from those employed in short-term forecasts are largely matters of degree. As we move further into the future, we must rely increasingly on long-time trends; relationships which are satisfactory for measuring year-to-year changes must be modified in the light of assumptions about the structure of the projected economy; and problems which are of relatively small concern in the short run assume greater importance when longer periods are considered. For example, the problem of the general price level assumes much greater significance in longer-run projections than it has in the short-term outlook.

\section{D. "WHAT PEACE CAN MEAN TO AMERICAN FARMERS"}

Between May and December 1945 the Bureau of Agricultural Economics published four reports under this title. ${ }^{2}$ The first described economic conditions likely to be associated with full employment or various levels of unemployment during the postwar years, and indicated probable effects of these different levels on prices and incomes received by farmers. The second report discussed the means of maintaining full employment, while the third was concerned with means of expanding foreign trade. The fourth report dealt with agricultural programs and policies appropriate to alternative conditions of domestic economic activity and foreign trade.

The first of these reports contains the first set of projections with which this paper is concerned. The key projections in the report are reproduced in Table 1. Their purpose was in large measure an educational one. As stated in the introductions:

"If farm people are to help develop constructive programs in the post-war period, they must understand their direct interest in national and international economic decisions which of necessity will be made at the close of this war-and understand the more basic relations of agricultural affairs to over-all national and international policies. The purpose of this analysis is to provide an aid to such understanding by describing the economic

2 Department of Agriculture, Misc. Pub. 562, May 1945; 570, July 1945; 582, October 1945; 589, December 1945. 
TABLE 1

Employment, Income, and Prices in the United States, 1935-39 Average, 1943, AND Estimates for 1950 under Assumed Conditions

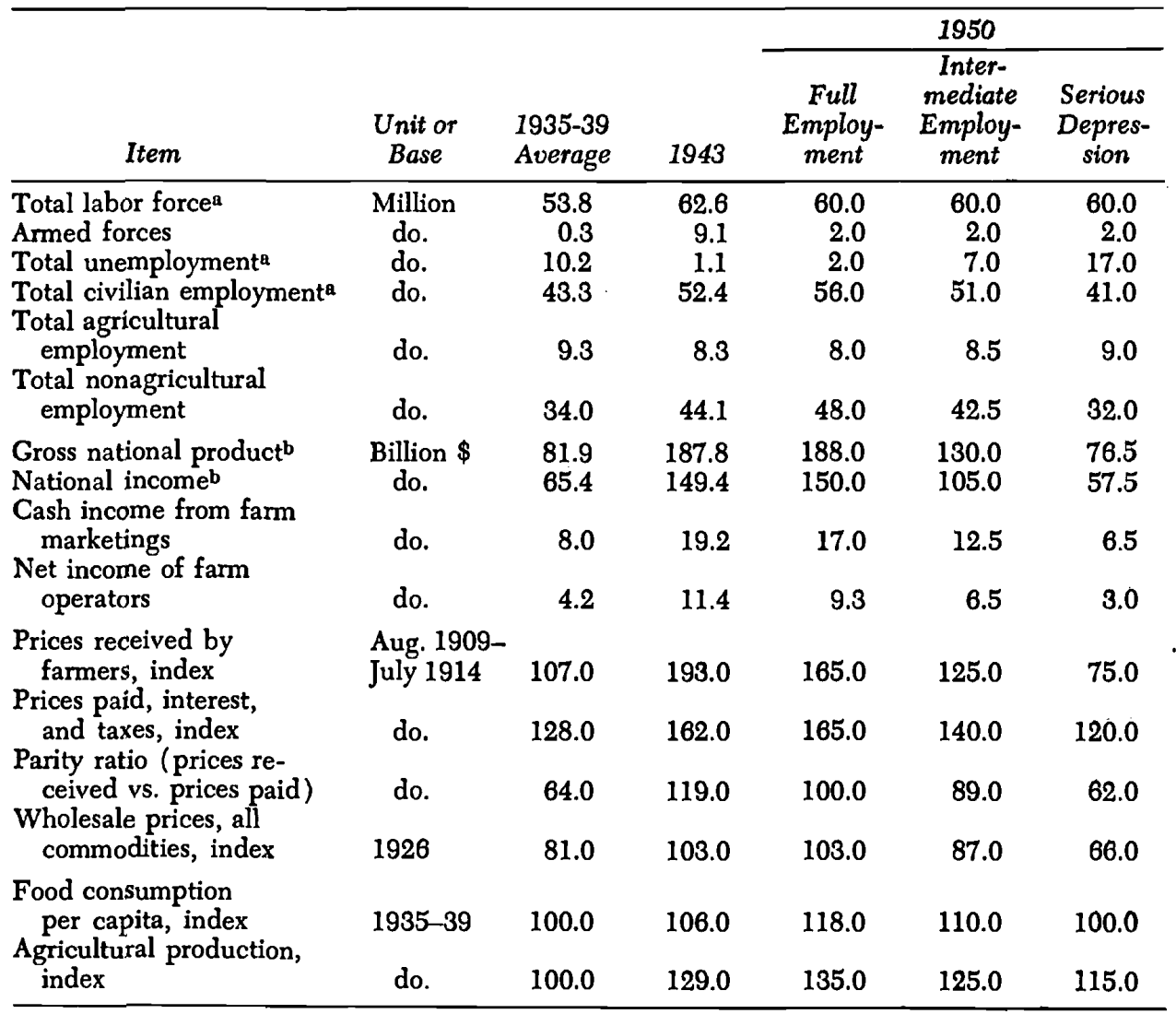

Revisions in data resulted in some differences for these items from comparable items in Table 3.

b Department of Commerce series as published prior to 1947. For differences between old and new series see "National Income and Product Statistics of the United States 1929-46," Supplement to Survey of Current Business, July 1947.

conditions likely to be associated with various degrees of employment and unemployment in the post-war period, and to indicate the most probable effect of these conditions on the price-andincome position of agriculture. The estimates presented are not forecasts of what will happen after the war, but are intended to illustrate what is most probable under stated alternative assumptions with respect to employment, price levels, productivity of labor, and related factors." 


\section{AGRICULTURE}

\section{Estimating procedures}

To estimate the total labor force in 1950 , we settled on an increase of approximately 1 percent a year from the total labor force reported by the Census for 1940 . An allowance of 2 million persons was made for the armed forces and an additional 2 million for frictional unemployment. These deductions gave a total civilian employment of 56 million persons, of which we assigned 8 million to agriculture. This last was lower than the number employed in any prewar year, and was designed to allow for the usual movement away from the farm during prosperity and for continuing technological advance in agriculture.

The next step was the estimation of gross national product and national income. These estimates were expressed in terms of the general price level in 1943, as indicated by the average level of the retail consumer price index. ${ }^{3}$ However, the agricultural components were adjusted downward because prices received by farmers in that year appeared to be about 15 percent above their normal relationship with the general price level. A compensating upward adjustment was made in the nonagricultural component.

Nonagricultural productivity levels in 1950 were estimated for two principal groups: group A-consisting of mining, manufacturing, transportation, electric power and gas utilities, and construction industries; and group B-consisting of wholesale and retail trade, finance, government, personal and professional services, and miscellaneous industries. Productivity per man-hour was estimated by fitting straight-line trends to the productivity data for each of the two groups. To obtain net income produced by each group, it was necessary to estimate the proportions of the 48 million nonagricultural workers that would be employed in the respective groups. For this purpose, we used the same proportions that prevailed in the high-employment year of 1929. This resuited in placing 20.6 million workers in group A and 27.6 million in group $B$.

An estimate of net real income produced by each of these groups in 1950 was obtained by multiplying the respective productivity indexes by the corresponding percentage increases in employment. These estimates of real net income were combined and converted to a total in terms of 1943 prices. This total amounted to approximately $\$ 134$ billion. To this was added $\$ 2$

\footnotetext{
${ }^{3}$ Consumers' price index of the Bureau of Labor Statistics.
} 


\section{AGRICULTURE}

billion for income produced by persons in the armed forces. On the basis of its past relationship to nonagricultural net income, agricultural net income was estimated at $\$ 14$ billion. The sum of these three estimates gave a national income of $\$ 150$ billion and a corresponding gross national product of $\$ 188$ billion.

Given these over-all assumptions with respect to national income and the general level of prices, price specialists in the Bureau developed an integrated pattern of production, disappearance, exports, imports, and prices for each of the principal agricultural commodities. In making these projections, it was further assumed that there would be no support-price or production control programs (except the sugar quota system); that exports would revert to approximately the prewar pattern; and that high levels of employment would prevail in the principal industrial countries of the world. Most of these individual commodity projections, including prices received by farmers, production, and exports, were published in this first report.

Estimates of domestic disappearance and exports were converted into equivalent farm marketings. Cash receipts from these marketings were derived by multiplying quantities marketed by corresponding estimates of prices received. The sum of the cash receipts from all items totaled $\$ 16.7$ billion, which was consistent with the net-income-produced figure of $\$ 14$ billion.

\section{Checking estimates}

Results of this general estimating process were subjected to certain cross-checks. The index of prices received by farmers, estimated on the basis of past relationships between that index and the consumer price index, approximately equaled the index resulting from the summation of the individual farm price projections. The cash receipts estimate of $\$ 16.7$ billion arrived at by the summation process proved lower than the results given by an over-all regression analysis, in which cash receipts were expressed as a function of national income and the value of agricultural exports. This equation indicated a level of $\$ 18$ billion. However, since the multiplier effect on farm income which this equation assigned to agricultural exports seemed suspiciously large, we relied on the results obtained in the individual commodity analyses, and used a final cash receipts figure of $\$ 17$ billion in the over-all model.

Estimates of domestic disappearance for food use at the farm 


\section{AGRICULTURE}

level were checked, and in some instances modified, on the basis of estimates of per capita consumption at the retail level. These per capita estimates were obtained by a combination of two approaches. First, a size distribution of the projected national income was constructed. The projected population was broken down by income groups, and estimates of consumption by these groups were obtained from income-group consumption data contained in the consumer purchases studies of 1935-36 and 1942." These were finally converted to estimated average consumption per capita. Secondly, estimates of per capita consumption of individual commodities were projected by time series analysis. Consumption of meats, dairy products, fats and oils, and sugar was estimated principally on the basis of correlation analyses in which consumption was regarded as a function of retail prices and per capita income. Consumption of other products, principally fruits, vegetables, and grains, was derived largely from longtime trends. When estimates from the two approaches were combined, they gave an index of per capita food consumption 18 percent above the 1935-39 level. This was consistent with a correlation analysis in which the index of per capita consumption of all foods was regarded as a function of disposable income per capita and the ratio of food prices to nonfood prices at retail. Furthermore, when the index of per capita food consumption was converted to an index of total consumption, it was found to be consistent with the index of total food production implicit in the individual commodity production estimates.

Estimates of domestic disappearance for nonfood use at the farm level were also checked by separate analyses, but it was not possible to do this as thoroughly as for the food items. However, the farm level projections for cotton and tobacco were fairly well substantiated by estimates of cotton consumption at the mill level and of cigarette consumption at the retail level. It was not possible to develop any definitive analysis of wool consumption. Projections of livestock product consumption were checked against projected feed supplies, prices, and trends in feeding efficiency in order to achieve internal consistency for this important input-output relationship.

In this first report, similar estimates were made within the

4 Consumer Expenditures in the United States (National Resources Committee, 1939); and Spending and Saving of the Nation's Families in Wartime (Bureau of Labor Statistics, Bul. 723, 1943). 
agricultural segment under conditions of intermediate employment and of serious depression. The intermediate situation was visualized as being analogous to the year 1941, and the serious depression as analogous to something between the very low level of 1932 and the average prewar level of 1935-39. The basic estimating procedures within these lower level assumptions were essentially the same as for the full-employment model.

In developing our projections for this report, we undertook to discuss the several models with agricultural economists in various sections of the country. A considerable number took rather strong exception to our full-employment model, which they regarded as improbable, if not fantastic. According to them, everyone knew that full employment was an unattainable ideal and that something like the agricultural depression of the 1930's would certainly reappear as soon as the war was overl Although we were not attempting actually to forecast conditions in the year 1950, we naturally hoped that it would turn out to be a year of approximately full employment. This would not only enable us to confound our critics, but, more important, would give us an opportunity of finding out whether or not we had been able to visualize the nature of a full-employment postwar economy with any degree of accuracy.

Unfortunately, the year 1950 was not ideally suited to this purpose. Conditions in this year ranged from continued decline in the economy during the first quarter, particularly with respect to agricultural prices and income, to an inflationary boom in the latter part of the year, arising out of the Korean situation. However, examination of quarterly data indicated that average conditions prevailed in the second and third quarters, approximating a full-employment situation not yet too seriously distorted by government expenditures for war purposes or by price inflation. Accordingly, I attempted to compare our 1950 projections made in 1944 with conditions as they existed in those two quarters converted to an annual basis. I reconstructed the 1944 projections using all original assumptions and relationships with the exception of the price level, where the actual indexes of consumer prices and wholesale prices were used. I did not attempt to work out the projection in all its commodity detail, but simply confined myself to over-all relationships between national income, on the one hand, and some of the principal items in the agricultural segment, on the other. Results are given in Table 2. 


\section{AGRICULTURE}

TABLE 2

Comparison of 1950 Full-Employment Projections Adjusted to 1950 Price Levels with Actual Conditions in Second and Third Quarters of 1950

\begin{tabular}{|c|c|c|c|c|}
\hline ITEM & $\begin{array}{l}\text { UNIT OR } \\
\text { BASE }\end{array}$ & $\begin{array}{c}1950 \text { FULI } \\
\text { PRoJ } \\
\text { Original } \\
\text { Projectionsa }\end{array}$ & $\begin{array}{l}\text { MPLOYMENT } \\
\text { rIONS } \\
\text { Adjusted } \\
\text { for } 1950 \\
\text { Price Levelb }\end{array}$ & $\begin{array}{c}\text { ACTUAL } 1950 \\
\text { (BASED } \\
\text { ON 2ND AND } \\
\text { 3RD QUARTERS) }\end{array}$ \\
\hline Total labor force & Million & 60.0 & 60.0 & 65.1 \\
\hline Armed forces & do. & 2.0 & 2.0 & 1.3 \\
\hline Total unemployment & do. & 2.0 & 2.0 & 3.0 \\
\hline $\begin{array}{l}\text { Total civilian employment } \\
\text { Total agricultural }\end{array}$ & do. & 56.0 & 56.0 & 60.8 \\
\hline $\begin{array}{l}\text { employment } \\
\text { Total nonagricultural }\end{array}$ & do. & 8.0 & 8.0 & 8.1 \\
\hline employment & do. & 48.0 & 48.0 & 52.7 \\
\hline $\begin{array}{l}\text { Gross national product } \\
\text { National income } \\
\text { Cash income from farm }\end{array}$ & $\begin{array}{l}\text { Billion } \$ \\
\text { do. }\end{array}$ & $\begin{array}{l}188.0 \\
150.0\end{array}$ & $\begin{array}{l}265.0^{\mathrm{c}} \\
225.0^{\mathrm{c}}\end{array}$ & $\begin{array}{l}277.7 \\
236.5\end{array}$ \\
\hline $\begin{array}{l}\text { marketings } \\
\text { Net income of farm operators }\end{array}$ & $\begin{array}{l}\text { do. } \\
\text { do. }\end{array}$ & $\begin{array}{r}17.0 \\
9.3\end{array}$ & $\begin{array}{l}23.6 \\
12.7\end{array}$ & $\begin{array}{l}27.5^{d} \\
13.0^{d}\end{array}$ \\
\hline $\begin{array}{l}\text { Prices received by farmers, } \\
\text { index } \\
\text { Prices paid, interest, and }\end{array}$ & $\begin{array}{l}\text { Aug. 1909- } \\
\text { July } 1 \mathrm{S14}\end{array}$ & 165.0 & 238.0 & 256.0 \\
\hline $\begin{array}{l}\text { taxes, index } \\
\text { Parity ratio (prices received }\end{array}$ & do. & 165.0 & 239.0 & 256.0 \\
\hline $\begin{array}{l}\text { vs. prices paid) } \\
\text { Wholesale prices, all } \\
\text { commodities, index }\end{array}$ & do. & 100.0 & 100.0 & 100.0 \\
\hline $\begin{array}{l}\text { Food consumption, per capita, } \\
\text { index } \\
\text { Agricultural production, index }\end{array}$ & $\begin{array}{l}1935-39 \\
\text { do. }\end{array}$ & $\begin{array}{l}118.0 \\
135.0\end{array}$ & $\begin{array}{l}118.0 \\
135.0\end{array}$ & $\begin{array}{l}112.0 \mathrm{e} \\
137.0^{\mathrm{e}}\end{array}$ \\
\hline
\end{tabular}

a From What Peace Can Mean to American Farmers, Department of Agriculture, Misc. Pub. $562,570,582,589$ (1945).

b 1950 projections calculated on same basis as in 1943, except for differences between actual and assumed general price levels.

c Including adjustment to bring these aggregates in line with Department of Commerce income concepts.

d Not available on an annual rate basis. Approximated from estimates of volume of farm marketings and prices received by farmers.

e Actual estimate for calendar year 1950. Not available on part-year basis.

\section{Comparison of estimates with actual}

Our projections of farm employment, farm income, prices received by farmers relative to prices paid, and the level of total agricultural production were fairly good. The projected level of food consumption was too high and our index of farm marketings, 


\section{AGRICULTURE}

which is not shown on this table, was too low relative to agricultural production. Disparity between the projected and actual situations was enhanced by the fact that agricultural exports in 1950 continued unusually high because of government aid programs, while the very considerable error in the population and labor force projections had pervasive influences on the estimates of the 1950 economy level which are very difficult to untangle. For example, there was no way of knowing offhand just how much of the miscalculation of the level of per capita consumption was due to population increase, how much to retarding factors in the production of meat, and how much to fundamental errors in the statistical relationships used in forecasting the consumption of food. I do not believe there is any point in pressing the comparison between actual and projected conditions much further. I shall leave the grading of this exercise to disinterested observers.

\section{E. AGRICULTURE LOOKS AHEAD}

There are both important differences and important similarities between the Hope Report and What Peace Can Mean to American Farmers. Although both studies contain projections of the economic condition of agriculture under various levels of economic activity, the Hope Report took the position that "in general it appears reasonable to expect a relatively high level of employment over the 25 years ahead" and that "the prospect for American agriculture over the next quarter century is relatively good" (p. 3). In analyzing the long-time prospects in this second report, we distinguished between certain long-run trends, which appeared to be of a rather stable nature, and certain variable factors, whose future behavior is more conjectural. Further comments on differences between the two reports will be made at the end of this section.

\section{Long-run trends}

With respect to long-run trends, we visualized a steady growth in the national economy as a whole. This growth is the result of upward trends in total population, labor force, and productivity per worker. The trend analysis of population is shown in Chart 1. On the basis of trends in gross national product per worker from 1880 to 1930 , we concluded that the long-time trend in productivity per worker probably lay within the range of 1.5 to 2 per- 


\section{AGRICULTURE}

cent a year. Assuming a population in 1975 midway between the high and medium projections in Chart 1 (that is, 174 million persons), a labor force of about 71 million, and-to avoid exaggerating the long-time trend-an average increase in productivity

\section{CHART 1}

Population in the United States, 1910-49;

Projected, 1950-75

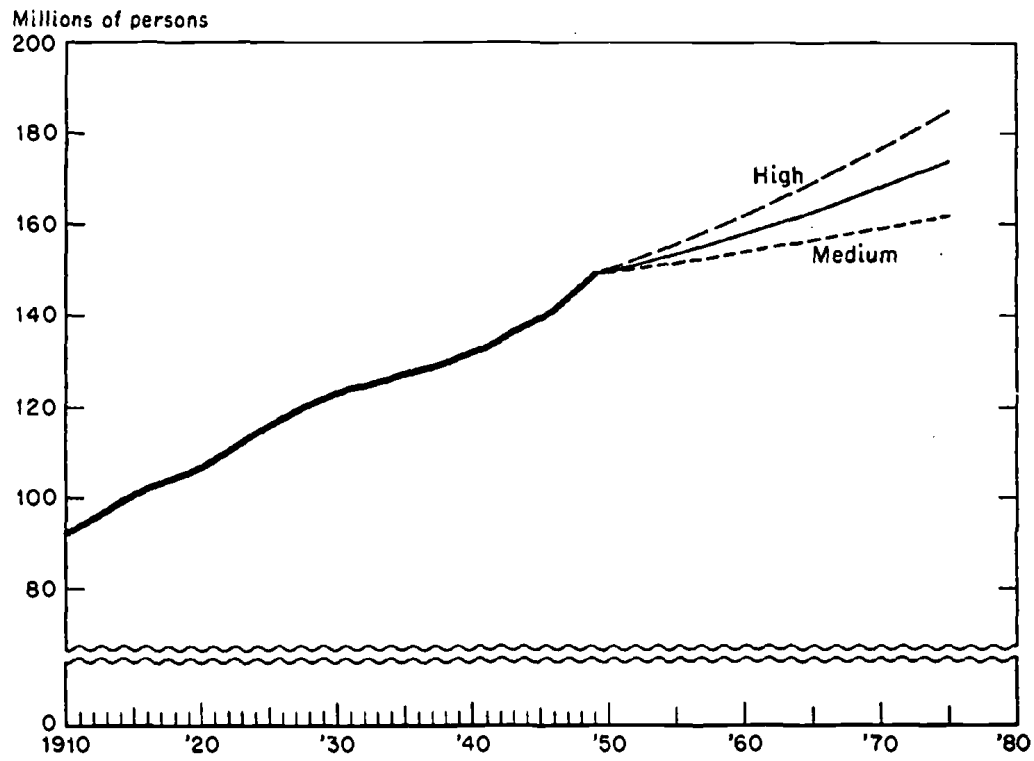

Basic total population. estimates are from the Bureau of the Census.

High projection based on high birth rates, low death rates, 200,000 annual net immigration. Medium projection based on medium birth rates and dealh rates, no nel immigration.

per worker of 1.5 percent a year, we derived a long-time trend for the gross national product. The comparable trend for disposable income in 1935-39 dollars is shown by the upper trend line in Chart 2.

We also visualized a long-time upward trend in farm output, despite a continued downward trend in farm population. The trend in farm population is shown in Chart 3 , while the trend in farm output, associated with a projected high level of economic activity, is shown in Chart 4 . Even with a declining farm population, it appears that agricultural production will continue to rise. Long-time upward trends in farm mechanization, production per unit of breeding livestock, and crop yields per acre were 


\section{AGRICULTURE}

\section{CHART 2}

Consumer Income in the United States, 1921-48;

Projected, 1950-75

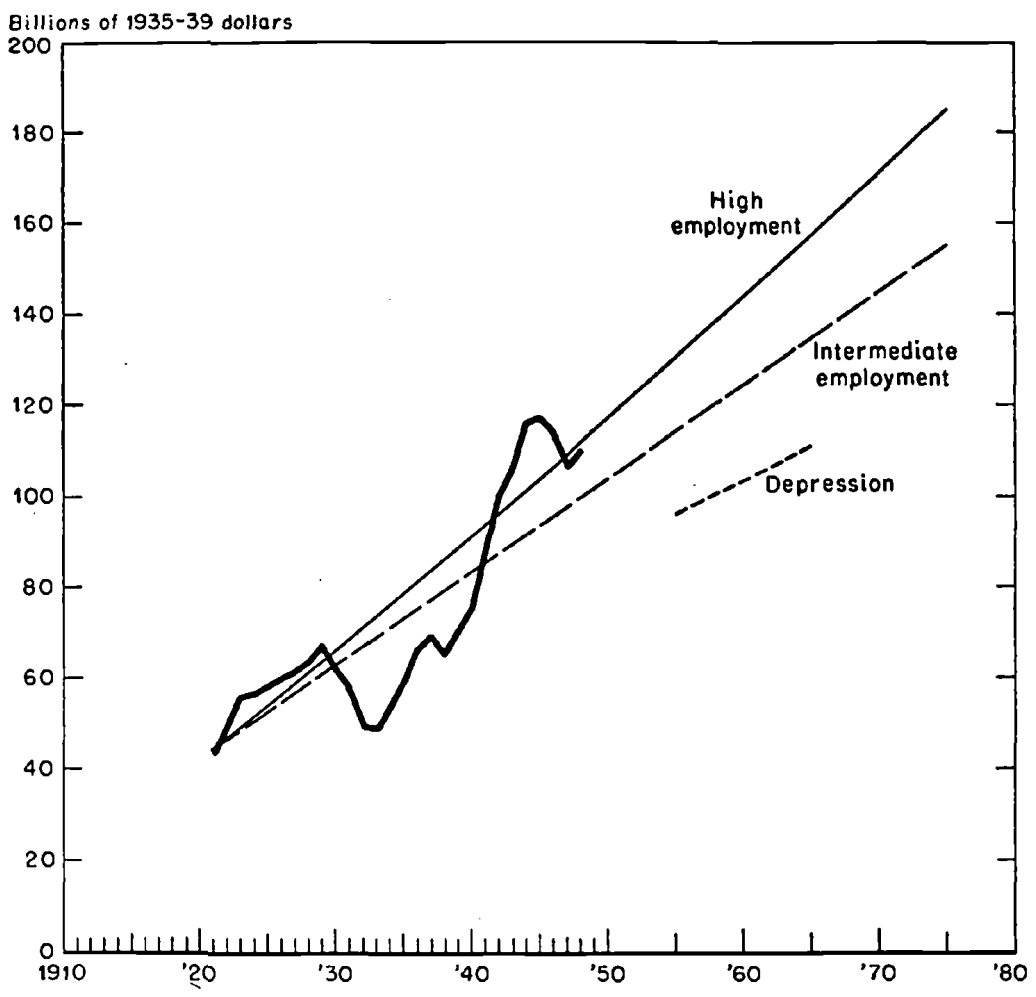

Disposable personal income in current dollars deflated by Bureau of Labor Statistics index of consumer prices.

assumed to be continuing agricultural characteristics. The increased crop yields were predicated on trends in fertilizer input, soil-conserving and soil-building practices, and the substitution of new land-created by drainage, irrigation, and clearing-for old land retired from cultivation. It should be noted here that the long-time projection of total farm output was based not only on analysis of trends in time series but also on a cooperative study carried out by the land-grant colleges and the United States Department of Agriculture. Assuming average weather and relatively favorable prices for farm products, committees in each state estimated what improved farm practices it would pay farmers to adopt and what the effects would be on crop yields. 


\section{AGRICULTURE}

\section{CHART 3}

Farm Population in the United States, 1910-49;

Projected, 1950-75

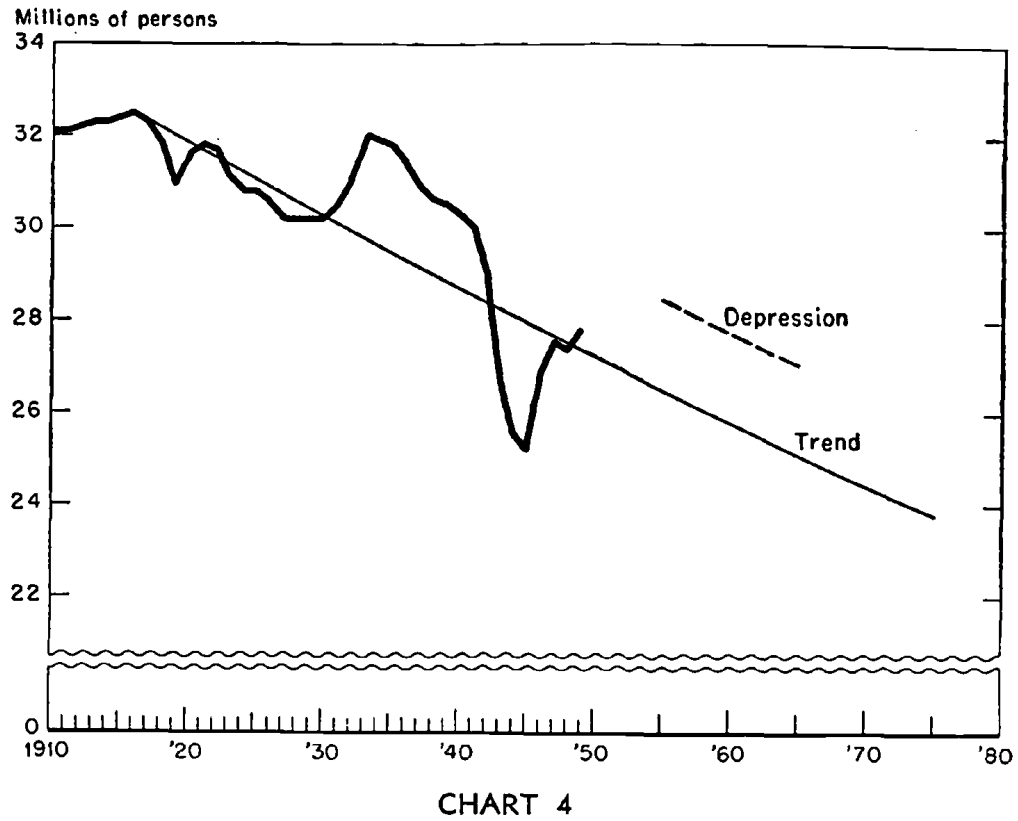

Farm Output in the United States, 1910-50;

Projected, 1951-75

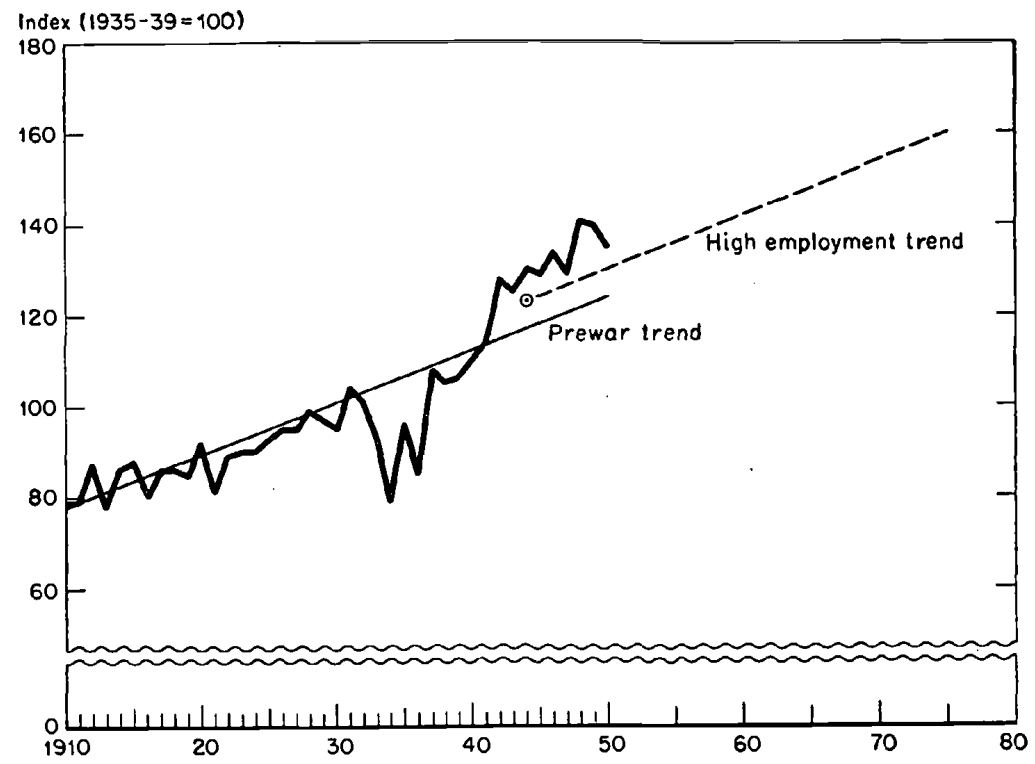

- 1942-46 average output adjusted for above average weather. 


\section{AGRICULTURE}

In addition, analysis was made of trends in farm costs, marketing costs, and food consumption. This report also discussed the continuing trends toward fewer and larger commercial farms, toward more part-time farms and rural residences, and toward the urbanization of rural life.

Following this presentation of selected long-run trends, we discussed what appeared to be the more variable factors-employment, the general price level, and the foreign demand for agricultural products-and presented a set of projections based on a number of alternative assumptions as to the general level of economic activity. These projections are given in Table 3 , and apply to the decade centering on 1960 .

The high-employment level in this model was based primarily on the trends selected as likely to be predominating influences over the next 25 years. It represents what was in our judgment the most probable economic environment in which agriculture would find itself in the long-run period. This is in contrast to the projections in What Peace Can Mean to American Farmers, where we did not attempt to determine which of the alternative situations calculated for the year 1950 was likely to prevail.

\section{Other problems}

Beside incorporating these long-time trends into the high-employment model, we dealt also with problems of the general level of prices, and the relation of farm prices and incomes to nonfarm prices and incomes.

It appeared to us that 1947 was characterized by a degree of price inflation that would not persist. Nonfood prices were markedly above their past relation to unit labor costs. We felt it advisable to bring this relationship back in line. After allowing for some further increase in wage rates during 1947, we assumed that the general price level would gradually adjust itself downward during the 1950's, with prospective increases in productivity per worker being about equally divided between increases in money wage rates and decreases in prices. We felt, therefore, that prices in the long-run postwar period under conditions of high employment would be something like 40 to 50 percent above 1935-39, but perhaps as much as 10 percent below those which prevailed in 1947. This was obviously a tentative approach to the long-run price level problem, but it did seem desirable to get away from the price abnormalities of the year 1947. Since then, the Bureau 
TABLE 3

Employment, Income, and Prices in the United States, 1935-39 Average, 1947, and Estimates for 1955-65 under Different Assumptions

\begin{tabular}{|c|c|c|c|c|c|c|}
\hline \multirow[b]{2}{*}{ ITEM } & \multirow[b]{2}{*}{$\begin{array}{l}\text { UNIT OR } \\
\text { BASE }\end{array}$} & \multirow[b]{2}{*}{$\begin{array}{l}1935-39 \\
\text { AVERAGE }\end{array}$} & \multirow{2}{*}{$\begin{array}{l}1947 \text { PRE- } \\
\text { LIMINARY }\end{array}$} & \multicolumn{3}{|c|}{$\begin{array}{c}\text { LTERNATIVE SITUATIONS, 1955-65 } \\
\text { Intermediate } \\
\text { Employment }\end{array}$} \\
\hline & & & & $\begin{array}{l}\text { Employ- } \\
\text { ment }\end{array}$ & $\begin{array}{c}\text { Average } \\
\text { Level }\end{array}$ & Depression \\
\hline $\begin{array}{l}\text { Total population } \\
\text { Total labor force } \\
\text { Employment } \\
\text { Unemployment }\end{array}$ & $\begin{array}{l}\text { Million } \\
\text { do. } \\
\text { do. } \\
\text { do. }\end{array}$ & $\begin{array}{r}129.0 \\
54.3 \\
44.9 \\
9.4\end{array}$ & $\begin{array}{r}144.0 \\
61.6 \\
59.5 \\
2.1\end{array}$ & $\begin{array}{r}158 \\
66 \\
62 \\
4\end{array}$ & $\begin{array}{r}154 \\
66 \\
58 \\
8\end{array}$ & $\begin{array}{r}154 \\
66 \\
53 \\
13\end{array}$ \\
\hline $\begin{array}{l}\text { Gross national product } \\
\text { Disposable income }\end{array}$ & $\begin{array}{l}\text { Billion \$ } \\
\text { do. }\end{array}$ & $\begin{array}{l}84.0 \\
66.2\end{array}$ & $\begin{array}{l}231.8 \\
175.6\end{array}$ & $\begin{array}{l}265 \\
200\end{array}$ & $\begin{array}{l}205 \\
155\end{array}$ & $\begin{array}{l}165 \\
130\end{array}$ \\
\hline $\begin{array}{l}\text { Cash receipts from farm } \\
\text { marketings } \\
\text { Realized net income of } \\
\text { farm operators } \\
\text { Net farm income to all } \\
\text { farm peopleb }\end{array}$ & do. & $4.8^{\mathrm{a}}$ & $18.0^{\mathrm{a}}$ & 14 & 17 & 11 \\
\hline $\begin{array}{l}\text { Consumer prices, index } \\
\text { Wholesale prices, index }\end{array}$ & $\begin{array}{l}1935-39 \\
1926\end{array}$ & $\begin{array}{r}100 \\
81\end{array}$ & $\begin{array}{l}159 \\
152\end{array}$ & $\begin{array}{l}145 \\
125\end{array}$ & $\begin{array}{l}125 \\
105\end{array}$ & $\begin{array}{r}115 \\
85\end{array}$ \\
\hline $\begin{array}{l}\text { Prices received by farmers, } \\
\text { index } \\
\text { Prices paid by farmers, }\end{array}$ & $1910-14$ & 107 & 278 & 200 & 150 & 100 \\
\hline $\begin{array}{l}\text { index } \\
\text { Ratio of prices received }\end{array}$ & do. & 128 & 231 & 200 & 175 & 150 \\
\hline $\begin{array}{l}\text { to prices paide } \\
\text { Farm output, index }\end{array}$ & do. & $\begin{array}{r}84 \\
100\end{array}$ & $\begin{array}{l}120 \\
129\end{array}$ & $\begin{array}{l}100 \\
143\end{array}$ & $\begin{array}{c}85 \\
138^{d}\end{array}$ & $\begin{array}{c}67 \\
133^{d}\end{array}$ \\
\hline $\begin{array}{l}\text { Food consumption per capita, } \\
\text { index }\end{array}$ & do. & 100 & 116 & 121 & 115 & 110 \\
\hline
\end{tabular}

a Includes government payments.

b Net income accruing from agriculture to all farm people, including farm laborers living on farms. Includes value of farm products consumed in the farm household and the rental value of the farm dwelling.

c Index of prices and rates paid by farmers, including allowance for interest and taxes.

d Probably exceeds, by small amounts, quantities marketable through normal channels at relative price levels specified.

of Agricultu:al Economics has given further attention to the price level problem involved in long-term projections.

We also faced the problem of agricultural prices and incomes in relation to nonagricultural prices and incomes. Although historical relationships between farm prices and income, on the one hand, and other economic variables, on the other hand, have given quite satisfactory results for short periods, there was doubt 


\section{AGRICULTURE}

as to their reliability for making long-run projections at levels of population and national income far beyond anything previously experienced. Unqualified use of these relationships gave forecasts of farm prices and incomes that appeared high. After taking into consideration the long-time downward trend in agricultural income as a percentage of national income, and introducing the assumption that under full employment the per capita income of persons on commercial farms would be roughly equivalent to incomes of persons not on farms, we found ourselves obliged to make decisions within a range. For a number of important agricultural series, these ranges were as follows: cash receipts from farm marketings, $\$ 23$ to 26 billion; prices received by farmers, 200 to $220(1910-14=100)$; and a parity ratio of 100 to 106 . A conservative choice was made in this matter, with weight being given to the uncertainty in export prospects, the possibility that the long-time trend in farm output may have been understated, and the further possibility that estimated per capita demand for food (as indicated by the index of average per capita food consumption) may have been too high. Events before Korea gave some indication that this conservatism may have been justified. Farm production had been running higher than the trend projections made in 1947 indicated, while farm prices had declined from a level of 306 in January 1948 to 233 in December 1949.

The parity ratio (the relation between the indexes of prices received and prices paid by farmers) was equal to 100 in both of these reports. Regardless of what one may think of the parity index as a means of determining individual commodity prices in connection with support-price and related farm programs, the parity ratio is a good statistical indicator of the general price position of agriculture relative to that of the rest of the economy of the United States. This ratio tends to fall well below 100 when the economy is operating under conditions of substantially less than full employment, to be fairly close to parity under conditions of full employment, and to move well above parity when there are abnormally large demands for agricultural products, such as developed during World War II and during the postwar period, when the demands arising out of foreign relief and reconstruction programs were added to the full-employment demands of the domestic economy.

I wish to emphasize that parity ratios in the two BAE reports 
were products of the projection process, rather than governing assumptions used in making the projections. However, the parity ratio used in the Hope Report might well have been anywhere within the range of 100-106 percent of parity. It was the conscious choice of a relatively conservative position with respect to the long-range agricultural price projections that resulted in the use of the lower figure.

In addition to the high or most probable level, this model also analyzes an average level and a depression level. These were constructed partly in recognition of the fact that a number of agricultural economists are much less optimistic about the long-run economic prospects for agriculture than the $\mathrm{BAE}$, and partly to illustrate the effect of large variations from the high-employment level. The latter constitutes the basic long-run projection of this report.

Projections for the average level assume that the economy will perform about as well as it did in the interwar period 1920-40. They assume also that the pattern of employment and prices would affect the basic trends envisioned in the high-employment model. Population and labor force would increase somewhat less rapidly; the annual increase in productivity per worker would drop to 1 percent a year; and agricultural production would expand at a slightly slower rate. Given lower levels of employment and output, prices would be expected to drop. This is illustrated by a decline of 14 percent in the consumer price index below the high-employment level. Agricultural prices and incomes are adjusted downward accordingly, showing their characteristic tendency to decline further than nonagricultural prices and incomes when the general level of economic activity drops. The general relation between this intermediate model and the highemployment level can be seen from the consumer disposable income projections in Chart 2.

This average level is regarded as a highly unstable situation. The depression model is designed to illustrate the type of cyclical drop that might occur if the economy lacked the basic strength to maintain itself at the high-employment level. The drastic assumptions used in this model are evident from an examination of the last column in Table 3.

I return now to certain differences between the projections in What Peace Can Mean to American Farmers and those in the Hope Report. The first report set out some alternative economic 


\section{AGRICULTURE}

possibilities for agriculture during the postwar period, together with suggestions of national policies that might serve to maintain full employment, and suggestions of appropriate agricultural policies under conditions of both full employment and underemployment. Projections in the Hope Report were focused on a more distant period and represented the Bureau's judgment as to which of the several alternatives was the most probable. The greater definiteness of the Hope Report arose out of the nature of the original request which the House Committee on Agriculture made to the Bureau. As Congressman Hope said in the Foreword to the report, "the committee felt that it would be helpful in its consideration of proposals for a long-time program to have before it the considered judgment of agricultural economists as to the major economic factors which may affect agricultural production, consumption, and prices for the next 25 years."

In some respects the projections in the first report were more complex than those in the second. They involved greater commodity detail, and a considerable effort was made to obtain consistency among all the individual commodity components and the larger aggregates. The second report was basically more aggregative, and contained fewer individual commodity projections. On the other hand, this report represented a greater effort to ascertain the likelihood that long-time trends would be continued or modified. A particular effort was made to arrive at a consensus as to the implication of these trends for the long-run outlook for agriculture.

It is impossible to say how "good" the projections in the Hope Report are. The Bureau has made a number of recalculations assuming a considerably larger population, and a somewhat higher level of total farm output and of prices generally. These adjustments, however, have not caused us to alter our views on the long-run prospects for agriculture, except perhaps in strengthening our conviction that the projection of a relatively high level of farm prices and incomes is justified.

\section{F. CURRENT PROGRESS IN AGRICULTURAL PROJECTIONS}

Despite the difficulties and hazards inherent in long-run projections, there are definite needs for them in the field of agricul- 
ture. Many programs affecting agriculture must be based on long-run considerations, and some attempt has to be made to formulate a framework of economic expectations. This is particularly true for such programs as flood control, forestry, and valley development, which require large-scale capital investments, and in which comparisons have to be made between current costs of these investments and the economic benefits which are expected to accrue. Projections are also becoming increasingly useful to agencies making repayable loans to farmers on a longterm basis. The abnormal conditions affecting agricultural prices over the past 20 years have rendered historical base periods less and less satisfactory as assumptions to be used in the development of lending standards. As a result there is an increasing tendency to employ projections of alternative future price situations for this purpose.

Because of this interest in long-run projections, the BAE has continued to work in this field. Its efforts have consisted, first, of more detailed projections, particularly for individual commodity prices, within the framework of the Hope Report; and secondly, of further analytic work on the general problem of long-run projections. The rest of this paper will be concerned with the latter.

Daly's study (the next paper in this volume) can properly be regarded as an extension and elaboration of the projection techniques employed in the Hope Report. Apart from the fact that his analyses center on the year 1970, as contrasted with 1955-65 in the earlier study, the principal new features are: (1) the construction of an index of total utilization of farm products, consisting of total domestic use of food plus total domestic use of nonfood commodities; (2) a more integrated analysis of the factors affecting food consumption over time; (3) a more searching analysis of the long-run influences affecting the proportion of gross national product and national income resulting from agricultural output; and (4) an explicit attempt to predict the behavior of the general price level during a prolonged period of full employment.

The construction of the index of total utilization of agricultural products, together with an over-all adjustment for net exports, permits a more direct, simpler comparison between projected total demand for farm products and projected total output than was achieved in the two previous BAE projections. 


\section{AGRICULTURE}

Daly projects a per capita food consumption index of 117 $(1935-39=100)$, compared with 121 in the Hope Report. The analyses underlying this projection bear out the belief that the projected level of per capita food consumption in the Hope Report was somewhat on the high side and that the index of 118 used in What Peace Can Mean to American Farmers was closer to the long-time full-employment level. However, the problem of the long-run level of food consumption has not yet been satisfactorily solved. Still in doubt are the effects of new dynamic elements-notably a continuing population shift from rural to urban areas, increased processing and preparation of food outside the home, and a rapidly rising population, bringing marked changes in age distribution. ${ }^{5}$ Large changes on the production side, particularly for meat, can have a significant influence on the level of food consumption as a whole. Furthermore, our statistical measures of food consumption and expenditures are still imperfect. Significant discrepancies between the BAE index of per capita food consumption and the estimates of consumer expenditures for food of the Department of Commerce need to be reconciled.

Daly's analysis of trends in trade between agriculture and the rest of the economy represents a more thorough exploration of this problem than was attempted in the Hope Report. It provides a firmer base for the final projection of farm output, prices received by farmers, and farm income than was available at the time when the earlier report was prepared.

The 1950 projections in What Peace Can Mean to American Farmers were in terms of the 1943 price level. The Hope Report assumed some contraction from the high prices prevailing in 1947, followed by a gradual downward adjustment in the general price level during the 1950's. Daly has attempted to deal more definitively with the long-run price level problem. Because of space limitations, his approach receives only brief treatment as now printed. It is therefore appropriate to summarize the essential steps involved. The core of his method was to examine trends in prices, total money supply, physical output, and money balances, in relaticn to gross national product in current dollars. This

${ }^{5}$ For a careful analysis of the postwar demand for food, see Marguerite C. Burk, "A Study of Recent Relationships between Income and Food Expenditures," Agricultural Economics Research (Bureau of Agricultural Economics), Vol. wI, No. 3, July 1951, pp. 87-97. 
analysis indicated a secular rise in the general price level. Daly did not accept the price level projection yielded by the trend analysis until he had examined the long-run relation of money wage rates to output, and had concluded that the economy has become increasingly resistant to severe price deflation. This involved an examination of the influence of political forces and of changes in our financial institutions on the general price level. Projected to 1970, his analysis indicated a price level about 30 percent higher than the one assumed in the Hope Report.

Daly's analysis is like the Hope Report, which attempted to deal explicitly with the long-run price level problem, rather than to follow the traditional method of using constant prices in the construction of a projected economic model. The essential reason for such a bold venture is the fact that the BAE projections have had a strong policy motivation. Demand for such projections has arisen as a result of long-range agricultural programs involving heavy financial commitments and requiring the adoption of assumptions as to the probable level of prices and incomes during the period when the fruits of these commitments will be realized. Despite the careful analysis made by Daly and the general plausibility of his findings, it is impossible to say whether his projected price level has any greater or less validity than the relatively conservative level projected in the Hope Report. I believe that his thesis of a gradual long-time rise in the price level under conditions of full employment is a better one than the assumption of a moderate decline adopted in the Hope Report. However, in view of the erratic behavior of farm prices since World War I, the disposition of the Department of Agriculture to take a relatively cautious position with respect to the long-run price level is understandable.

Although the final projections of the general level of prices, as well as those of prices received and paid by farmers, are considerably higher in Daly's study than in the Hope Report, the relationship between prices received and prices paid (the parity ratio) remains within the Hope Report range of 100 to 105. This indicates that the judgment of the BAE concerning the relative position of agriculture in a future high-level economy has not been fundamentally altered. ${ }^{6}$ The projected farm income figures

o Since this present paper was written, however, there have been indications that the continuance of rapid technological change in agricultural production, together with the impact of the Korean inflation on the farm cost 


\section{AGRICULTURE}

in the Daly model are substantially higher than in the Hope Report, due to the assumption of both a rising price level and a larger farm output. However, they represent a somewhat lower share of total national income because of the assumption that the historical decline in the agricultural share will still be characteristic of the economy in 1970, which is considerably further out in time than the dates for the income projections in the Hope Report.

\section{G. CONCLUDING REMARKS}

The projection process followed in the Hope Report and carried forward by Daly can be summarized in a general fashion. Attention is first centered on trends that might be regarded as exogenous as far as agriculture is concerned, such as population, labor force, productivity, and the general price level. On the basis of these trends, there is projected a framework for the economy as a whole, consisting of a few large aggregates such as gross national product, national income, and a general price index. Secondly, trends are projected for a considerable number of variables within the agricultural segment, giving weight not only to observable long-time movements in the variables themselves, but also to the influences which the projected framework for the economy as a whole might be expected to exert on these movements. When trend projections for the more important components of the agricultural segment are given, an attempt is made to establish a rough equilibrium between agriculture and the rest of the economy. In establishing this equilibrium, certain historical relationships are utilized (arrived at by single equation methods), but their utilization is subject to modification on the basis of any evident trends in these relationships or on the basis of any other knowledge which appears to indicate that changes can be expected during a lengthy time period. Finally, an attempt is made to establish a more precise equilibrium within agriculture itself, partly by checking projections for individual commodities against projections for aggregates containing these commodities, and partly by analyzing the consistency of the inputoutput relationships that the agricultural projections imply.

The foregoing process of formulating long-range projections in

structure, may result in a ratio of prices received to prices paid closer to 95 than to 100 , even under conditions of full employment. 


\section{AGRICULTURE}

agriculture can hardly be described as a method, in the sense of consisting of a definite number of steps, taken in unvarying sequence, and employing a fixed set of statistical relationships. It does, however, involve the use of an enormous amount of quantitative data and scores of statistical relationships. More importantly, it is a synthesis of the economic judgment of a large number of trained and experienced analysts concerned with practically every field within the economics of agriculture.

In concluding, I should like to emphasize again the difference between our projections for the economy as a whole and those for agriculture as such. We feel rather confident that, given a set of over-all projections, we can construct a reasonably good set of projections for agriculture. But unless our framework projections are good, our agricultural projections will be defective. Future progress in our projective efforts will in very large degree depend on the development of satisfactory methods for projecting those large critical components which determine the general level of employment, output, and income. It is relatively easy for us to make agricultural projections under various alternative assumptions of the general level of economic activity, but the payoff comes when one has to indicate which of the several alternatives is the one most likely to prevail. So far, we have leaned in the direction of thinking that our "high employment" projections represent the most probable course of economic development in this country over the next 25 years or so, and we hope that the projectors of population, productivity, capital formation, and the like will bear us out. 